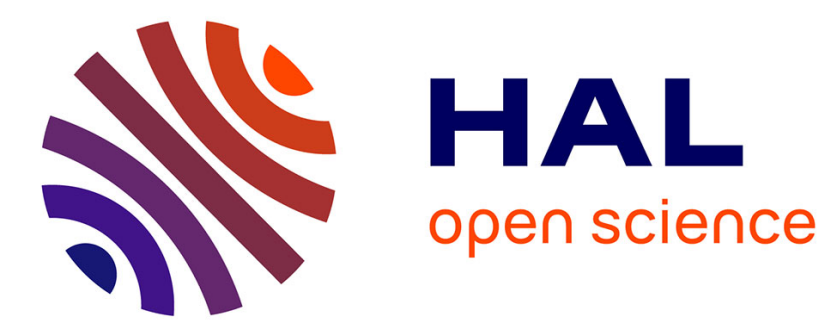

\title{
A new species of Hauptmannia (Acari: Erythraeidae) from Montenegro
}

\author{
A. Saboori, M. Sundic, V. Pesic, M. Hakimitabar
}

\section{To cite this version:}

A. Saboori, M. Sundic, V. Pesic, M. Hakimitabar. A new species of Hauptmannia (Acari: Erythraeidae) from Montenegro. Acarologia, 2011, 51 (1), pp.61-68. 10.1051/acarologia/20111989 . hal-01599936

\section{HAL Id: hal-01599936 \\ https://hal.science/hal-01599936}

Submitted on 2 Oct 2017

HAL is a multi-disciplinary open access archive for the deposit and dissemination of scientific research documents, whether they are published or not. The documents may come from teaching and research institutions in France or abroad, or from public or private research centers.
L'archive ouverte pluridisciplinaire HAL, est destinée au dépôt et à la diffusion de documents scientifiques de niveau recherche, publiés ou non, émanant des établissements d'enseignement et de recherche français ou étrangers, des laboratoires publics ou privés.

\section{(ㅇ)(1) $\$$}

Distributed under a Creative Commons Attribution - NonCommercial - NoDerivatives $\mid 4.0$ 


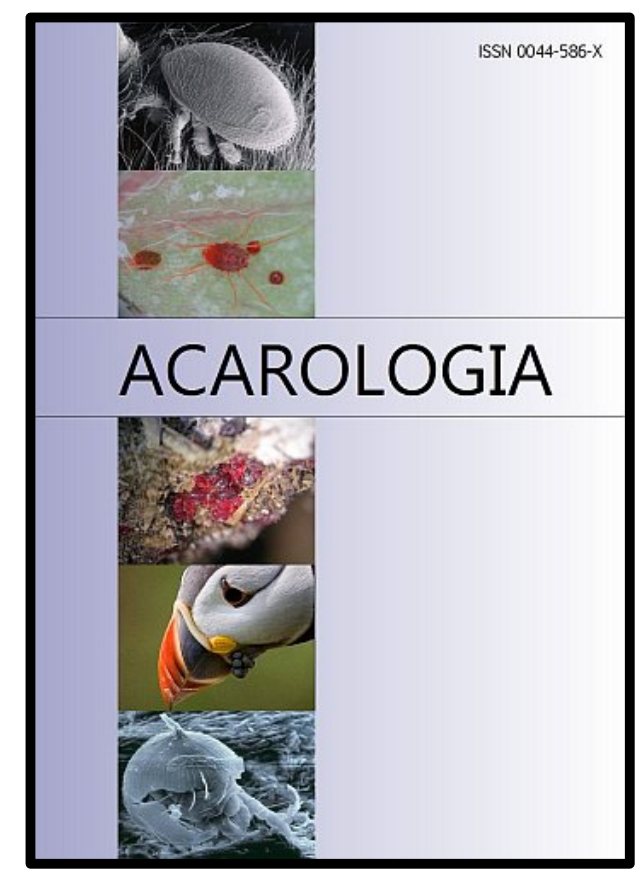

\section{ACAROLOGIA}

A quarterly journal of acarology, since 1959

Publishing on all aspects of the Acari

All information:

http://www1.montpellier.inra.fr/CBGP/acarologia/ acarologia@supagro.inra.fr

\section{OPEN ACCESS}

\section{Acarologia is proudly non-profit, with no page charges and free open access}

Please help us maintain this system by encouraging your institutes to subscribe to the print version of the journal and by sending us your high quality research on the Acari.

Subscriptions: Year 2017 (Volume 57): $380 €$ http://www1.montpellier.inra.fr/CBGP/acarologia/subscribe.php

Previous volumes (2010-2015): $250 € /$ year (4 issues)

Acarologia, CBGP, CS 30016, 34988 MONTFERRIER-sur-LEZ Cedex, France

The digitalization of Acarologia papers prior to 2000 was supported by Agropolis Fondation under the reference ID 1500-024 through the « Investissements d'avenir » programme

(Labex Agro: ANR-10-LABX-0001-01)
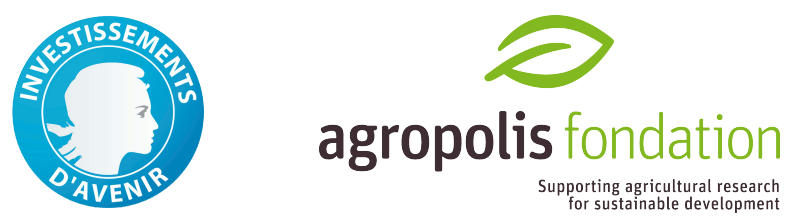

Acarologia is under free license and distributed under the terms of the

Creative Commons-BY-NC-ND which permits unrestricted non-commercial use, distribution, and reproduction in any medium, provided the original author and source are credited. 


\title{
A NEW SPECIES OF HAUPTMANNIA (ACARI: ERYTHRAEIDAE) FROM MONTENEGRO
}

\author{
Alireza SABOORI ${ }^{1}$, Miloje ŠUndiĆ ${ }^{2}$, Vladimir PEŠIĆ ${ }^{2}$ and Masoud HAKIMITABAR ${ }^{1}$ \\ (Received 20 June 2010; accepted 15 July 2010; published online 30 March 2011) \\ ${ }^{1}$ Department of Plant Protection, College of Agriculture, University of Tehran, Karaj, Iran. \\ saboori@ut.ac.ir, hakimitabar@yahoo.com \\ ${ }^{2}$ Department of Biology, Faculty of Sciences, University of Montenegro, Cetinjski put b.b., 81000 Podgorica, Montenegro. \\ miloje@t-com.me, pesicv@t-com.me
}

ABSTRACT - Hauptmannia striata Saboori, S̆undić \& Pešić, n. sp. is described and illustrated from larvae ectoparasitic on unidentified Collembola from Montenegro. It is the first report of the genus Hauptmannia and the fourth species of Erythraeidae found to be ectoparasitic on Collembola.

KEYWORDS - Hauptmannia striata Saboori, Sundić \& Pešić, n. sp.; Collembola; ectoparasite; larva; new host; Montenegro

\section{INTRODUCTION}

The larvae of the Erythraeidae are parasites of various arthropods, including insects and spiders whereas postlarval erythraeids are predators. Some erythraeids (e.g. Balaustium sp.) are important predators of different pests (e.g. Zeiraphera diniana Guénée, Panonychus ulmi (Koch)) (Gerson et al., 2003).

Fauna of terrestrial Parasitengona of Montenegro is poorly known. Only four species of the family Erythraeidae have been reported from Montenegro: Erythraeus (Zaracarus) budapestensis Fain and Ripka, 1998, Erythraeus (Erythraeus) ankaraicus Saboori, Çobanoğlu and Bayram, 2004, Erythraeus (Zaracarus) cf. ueckermanni Saboori, Nowzari and Bagheri-Zenouz, 2004, and Hauptmannia kotorensis Haitlinger, 2007 (Haitlinger 2007a; Saboori et al. 2008). Mites have been less commonly recorded with the order Collembola (Greenslade and Southcott 1980). Only three species of erythraeids have been reported as ectoparasite of Collembola: Leptus (Leptus) southcotti Beron, 1975, Leptus (Leptus) trimaculatus (Rossi, 1794), both on unidentified Collembola from Bulgaria and Erythrites sp. near womersleyi (Southcott, 1946) on Corynephoria quadrimaculata Womersley, 1942 and Corynephoria sp. from Australia (Southcott, 1946; Beron 1975, 2008; Greenslade and Southcott 1980). In this paper we describe the larva of Hauptmannia striata Saboori, S̆undić \& Pešić, n. sp. ectoparasitic on an unidentified Collembola from Podgorica, Montenegro.

\section{MATERIAls AND Methods}

Collembola specimens were collected by a sweep net and preserved in $75 \%$ ethanol. 


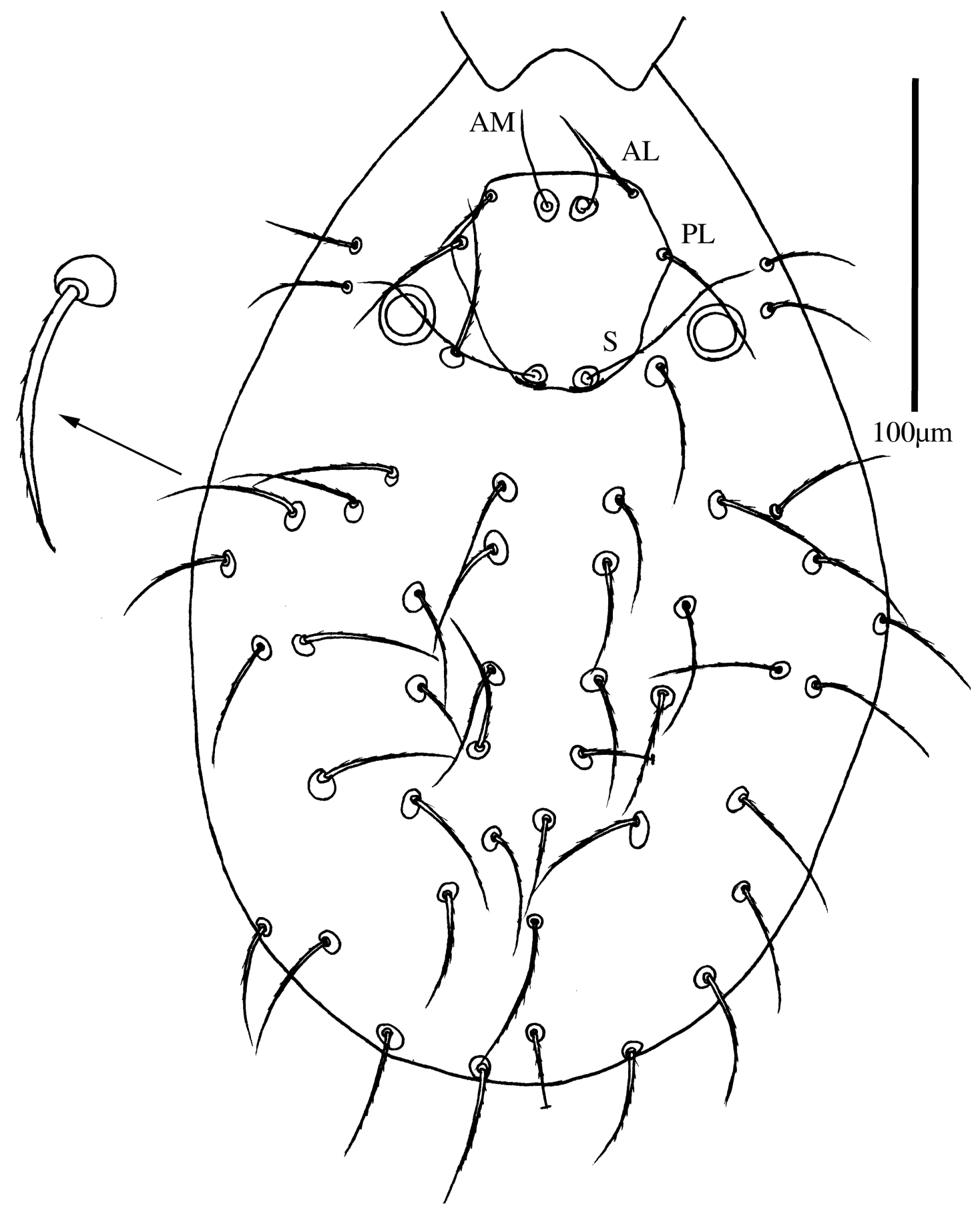

Figure 1: Hauptmannia striata Saboori, S̆undić \& Pešić, n. sp. (larva). Dorsal view of idiosoma. 


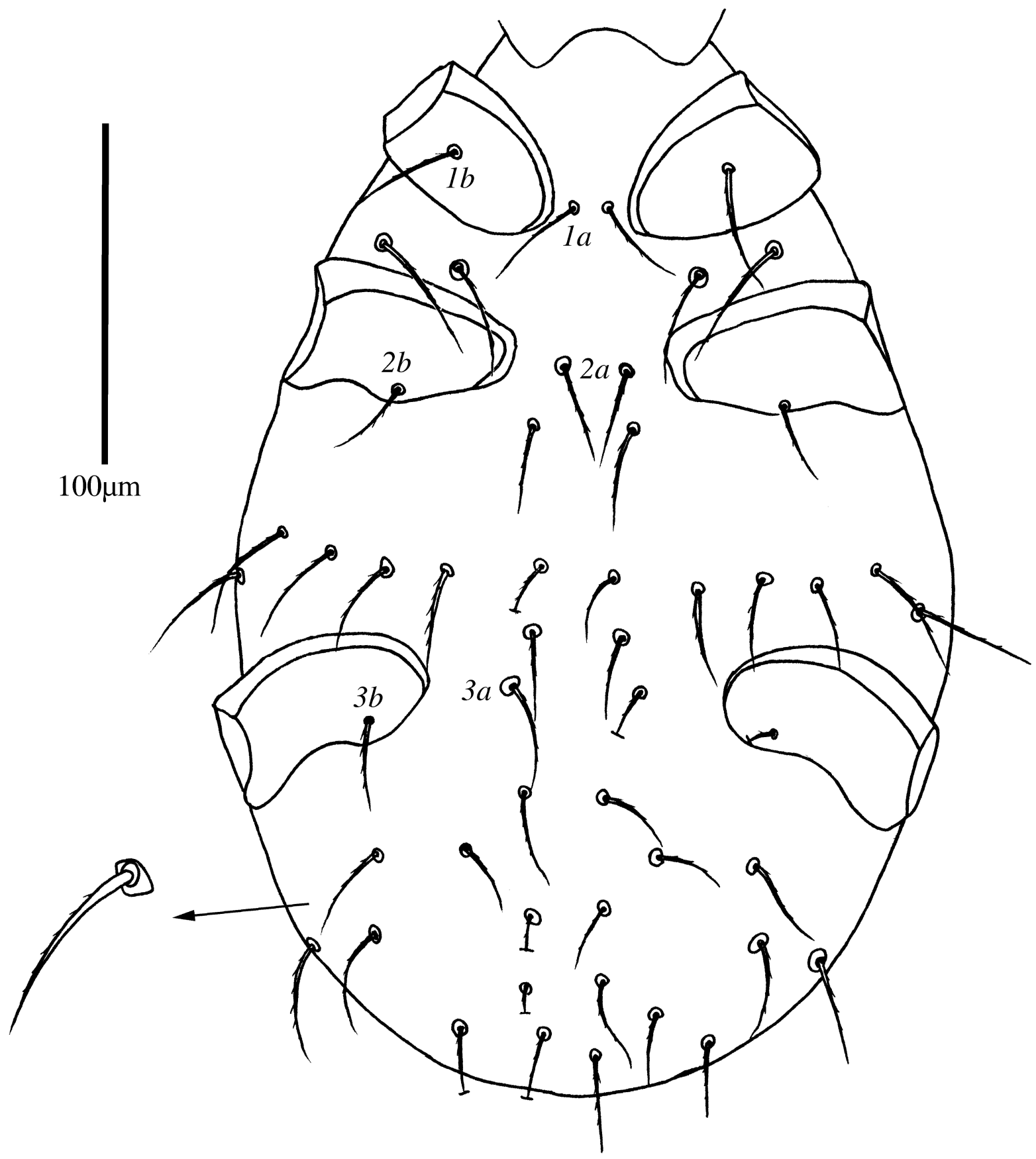

FIgURE 2: Hauptmannia striata Saboori, S̆undić \& Pešić, n. sp. (larva). Ventral view of idiosoma. 


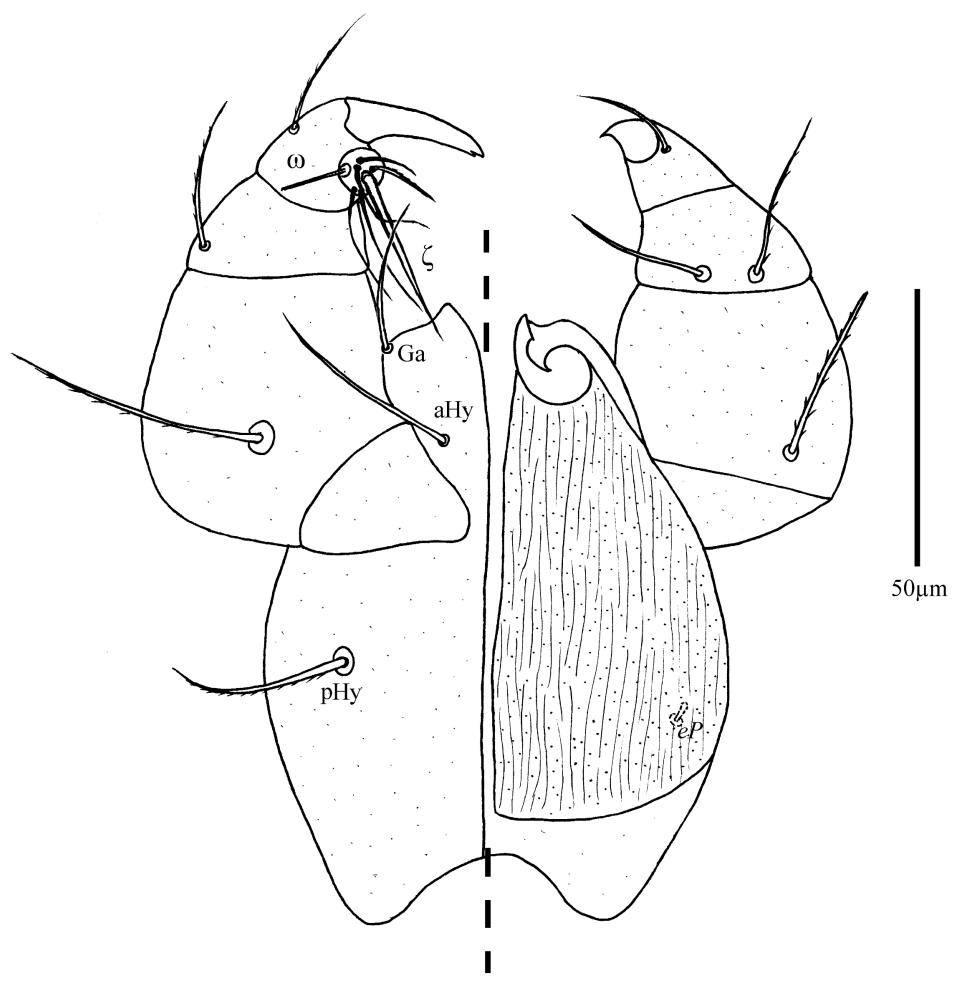

FIGURE 3: Hauptmannia striata Saboori, Šundić \& Pešić, n. sp. (larva). Dorsal view (right) and ventral view (left) of gnathosoma.

Mite specimens were detached by an insect pin, cleared in Nessbitt's solution and mounted in Faure medium (Walter and Krantz 2009). Figures were drawn and measurements were calculated using a BX51 Olympus microscope equipped with a drawing tube and zoom lens.

The terminology and abbreviations follow Saboori et al. (2009) and all measurements are given in micrometers $(\mu \mathrm{m})$.

\section{FAMILY ERYTHRAEIDAE}

\section{Hauptmannia striata Saboori, Šundić \& Pešić, $\mathbf{n}$.} sp. (Figs. 1 - 4)

\section{Diagnosis}

Palpal tibial claw bifid, palpal accessory claw entire, cheliceral bases striated and punctate, fn Ti 12-1313.

Larva (Holotype) - Idiosoma oval, dorsal surface with 46 setae with fine barbs and on platelets
(Fig. 1). Scutum length and width equal, scutum punctate with 2 pairs of scutalae; PL longer than AL; both with fine barbs. Anterior pair of sensilla (AM) very short and smooth; posterior pair of sensilla (S) with fine barbs throughout the length (Fig. 1). Each side of scutum with one eye, circular, not on platelets; eyes 15 , ocular ring 20 across.

Ventral surface of idiosoma bearing 6 sternalae, 4 setae between coxae I and II, 16 barbed setae between coxae II and III and 19 setae behind coxae III. All ventral setae with fine barbs. Sternalae more or less equal in length. Coxae I-III each with one seta; coxala $1 b$ longer than other coxalae; coxala $2 b$ about as long as coxala $3 b$; all coxalae barbed (Fig. 2). $\mathrm{NDV}=46+39=85$.

Gnathosoma with smooth galealae (Ga) and anterior hypostomalae (aHy) and barbed posterior hypostomalae (pHy) (Fig. 3). Palpal femur with 2 barbed and genu with 1 nude and 2 barbed setae (Fig. 3). Tibia with 1 barbed and 1 nude seta and an entire accessory claw. 
TABLE 1: Metric data of Hauptmannia striata n. sp. larvae (a, holotype; b-d, paratypes).

\begin{tabular}{|c|c|c|c|c|}
\hline Character & a & $\mathbf{b}$ & c & d \\
\hline IL & 332 & 430 & 421 & 445 \\
\hline IW & 111 & 208 & 215 & 238 \\
\hline SD & 74 & 73 & 74 & 75 \\
\hline W & 74 & 73 & 74 & 75 \\
\hline $\mathrm{AW}$ & 46 & 52 & 48 & 50 \\
\hline PW & 64 & 66 & 64 & 65 \\
\hline MA & 17 & 17 & 18 & 17 \\
\hline AA & 12 & 10 & 12 & 15 \\
\hline SB & 17 & 19 & 17 & 18 \\
\hline ISD & 54 & 57 & 52 & 62 \\
\hline $\mathrm{AP}$ & 21 & 14 & 14 & 22 \\
\hline AL & 28 & 26 & - & 30 \\
\hline PL & 46 & 45 & 42 & 47 \\
\hline $\mathrm{AM}$ & 38 & 33 & 42 & 37 \\
\hline$S$ & 63 & 50 & 59 & 61 \\
\hline DS & $41-48$ & $31-46$ & $30-47$ & $30-47$ \\
\hline PDS & $37-47$ & $44-54$ & $40-47$ & $35-50$ \\
\hline $1 a$ & 32 & 28 & 32 & 27 \\
\hline $1 b$ & 51 & 63 & 50 & 50 \\
\hline $2 a$ & 32 & 26 & 32 & 27 \\
\hline $2 b$ & 28 & 25 & 27 & 35 \\
\hline $3 a$ & 30 & 26 & 27 & 30 \\
\hline $3 b$ & 28 & 25 & 27 & 30 \\
\hline GL & 114 & 120 & 121 & 121 \\
\hline PaScFed & 33 & 32 & 39 & - \\
\hline PaScFev & 50 & 48 & 51 & 50 \\
\hline $\mathrm{PaScGed}_{1}$ & 32 & 30 & 37 & 35 \\
\hline $\mathrm{PaScGed}_{2}$ & 35 & 32 & 42 & 35 \\
\hline PaScGev & 25 & 27 & 27 & 27 \\
\hline aHy & 42 & 31 & 30 & 52 \\
\hline
\end{tabular}

Tarsus with 7 setae including one barbed and four nude normal setae, a solenidion and an eupathidium (Fig. 3). $\quad \mathrm{fPp}=0-\mathrm{BB}-\mathrm{BBN}-\mathrm{BNN} 2-$ BNNNN $\omega \zeta$. Palps and ventral gnathosoma with fine punctation. Cheliceral bases striated and punctate. Supracoxal seta of palp $(e P) 5$ long.

Leg segmentation formula: 7-7-7. Leg setal formula: Leg I: Ta- $1 \omega, 1 \varepsilon, 2 \zeta, 1 \mathrm{Cp}, 24 \mathrm{n}$; Ti- $2 \varphi, 1 \kappa, 12 \mathrm{n}$; Ge- $1 \sigma, 1 \kappa, 11 \mathrm{n}$; TFe- $8 \mathrm{n}$; BFe- 4n; Tr- 2n; Cx- $1 \mathrm{n}$ (+ 1 $e P)$ (Fig. 4A). Leg II: Ta- $1 \omega, 2 \zeta, 1 C p, 21 n ;$ Ti- $2 \varphi, 13 n$; Ge- $1 \sigma, 1 \kappa, 9 n$; TFe- 5n; BFe- 4n; Tr- 2n; Cx- 1n (Fig. 4B). Leg III: Ta- $1 \zeta, 18 n$; Ti- $1 \varphi, 13 n$; Ge- $1 \sigma, 9 n$; TFe-

\begin{tabular}{lcccc}
\hline Character & a & b & c & d \\
\hline pHy & 37 & 33 & - & 37 \\
Ga & 35 & 31 & 30 & 27 \\
Ta I (L) & 66 & 64 & 62 & 65 \\
Ta I (H) & 28 & 36 & 27 & 27 \\
Ti I & 64 & 69 & 69 & 70 \\
Ge I & 67 & 65 & 62 & 67 \\
TFe I & 33 & 33 & 32 & 35 \\
BFe I & 50 & 50 & 35 & 42 \\
Tr I & 47 & 50 & 37 & 37 \\
Cx I & 60 & 59 & 52 & 57 \\
Leg I & 387 & 390 & 349 & 373 \\
Ta II (L) & 60 & 54 & 54 & 57 \\
Ta II (H) & 25 & 25 & 27 & 26 \\
Ti II & 64 & 62 & 62 & 67 \\
Ge II & 64 & 57 & 62 & 64 \\
TFe II & 30 & 30 & 27 & 32 \\
BFe II & 41 & 42 & 32 & 37 \\
Tr II & 42 & 45 & 47 & 50 \\
Cx II & 77 & 67 & 62 & 69 \\
Leg II & 378 & 357 & 346 & 376 \\
Ta III (L) & 61 & 57 & 55 & 57 \\
Ta III (H) & 22 & 25 & 25 & 22 \\
Ti III & 90 & 89 & 89 & 97 \\
Ge III & 75 & 74 & 74 & 79 \\
TFe III & 38 & 37 & 37 & 42 \\
BFe III & 45 & 28 & 45 & 42 \\
Tr III & 50 & 42 & 50 & 45 \\
Cx III & 71 & 69 & 62 & 67 \\
Leg III & 430 & 396 & 412 & 429 \\
IP & 1195 & 1143 & 1107 & 1178 \\
\hline & & & &
\end{tabular}

5n; BFe- 4n; Tr- 2n; Cx- 1n (Fig. 4C). All tarsi with two falciform claws and a claw-like empodium.

Measurements are given in Table 1.

\section{Etymology}

Name referring to the striations on cheliceral bases.

\section{Type material}

The holotype (ARS-20041115-1a) and paratype (ARS-20041115-1b, 1c, 1d) larvae were collected by A. Saboori, M. Šundić \& Pešić, ectoparasitic on 

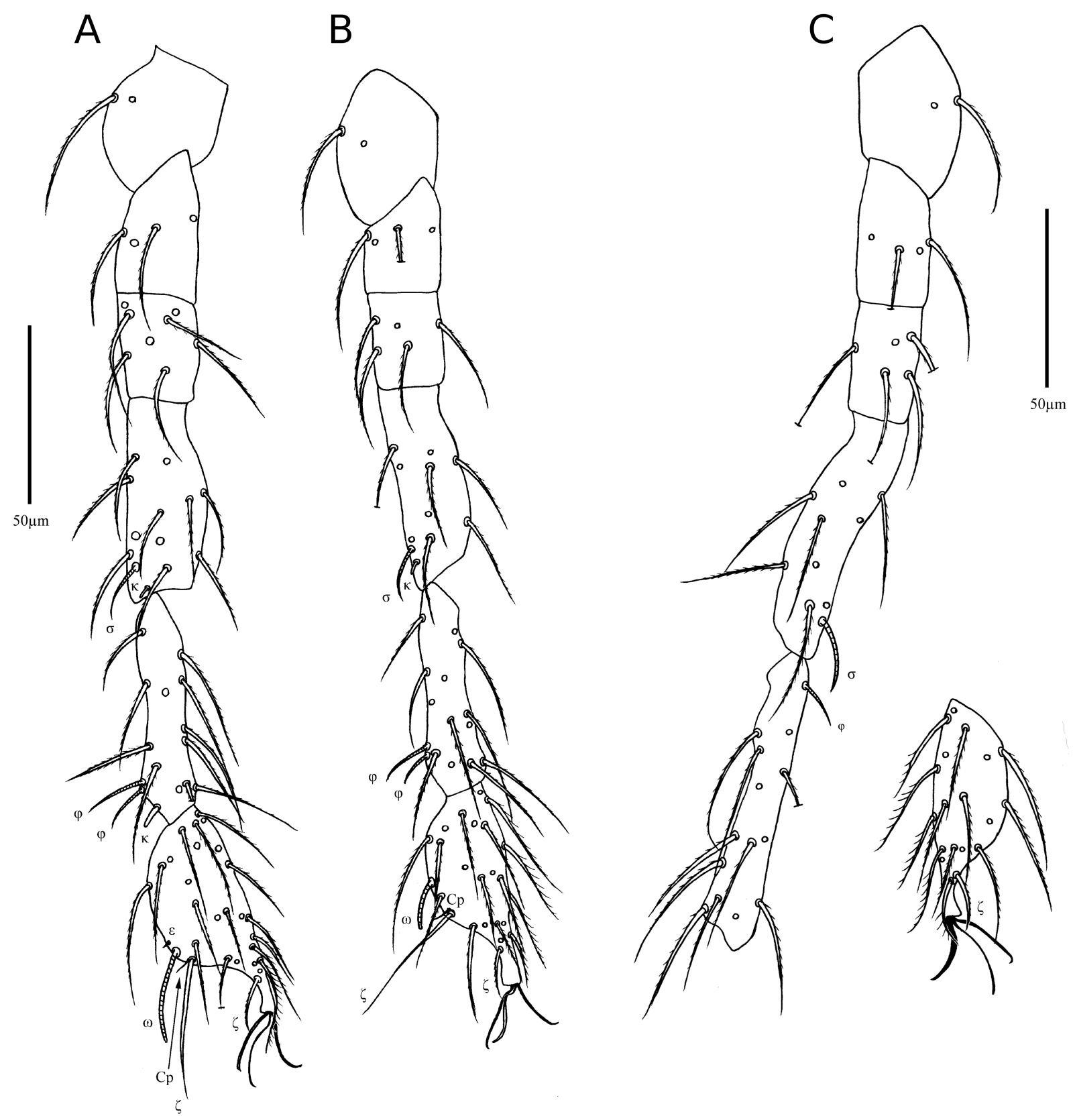

FIgURE 4: Hauptmannia striata Saboori, Šundić \& Pešić, n. sp. (larva). A - Leg I, trochanter-tarsus; B - Leg II, trochanter - tarsus; C - Leg III, trochanter - tarsus. 
unidentified Collembola, 8 August 2008, in Vranjske Njive ( $42^{\circ} 28^{\prime} 06.96^{\prime \prime} \mathrm{N} 19^{\circ} 15^{\prime} 28.10^{\prime \prime}$ E), bank of Zeta River, Podgorica, Montenegro. The holotype and one paratype (ARS-20030611-1b) are deposited in the Acarological Collections, Jalal Afshar Zoological Museum, College of Agriculture, University of Tehran, Karaj, Iran and two paratypes are deposited in the Museum of the Natural History of Podgorica (Montenegro).

\section{Remarks}

It is the fourth species of Erythraeidae as ectoparasite of Collembola. Hauptmannia striata Saboori, Šundić \& Pešić, n. sp. belongs to the species group of Hauptmannia with bifid palpal tibial claw (Haitlinger 2008a). There are seven species in this group as follows: Hauptmannia stanislavae Haitlinger, 1986, H. silesiacus Haitlinger, 1986, $H$. viburnicola Fain and Çobanoğlu, 1998, H. yanlingica Zheng, 2002, H. sardiniensis Haitlinger, 2007, H. kotorensis Haitlinger, 2007 and H. podorasensis Haitlinger 2007. It differs from all these species by striated and punctate cheliceral bases. Also, it differs from $H$. stanislavae by longer AW (46-52 vs. 34 - 40), PW (64- 66 vs. $52-56)$, PL ( $42-47$ vs. $24-$ 30), AM ( $33-42$ vs. $26-30), \mathrm{S}(50-63$ vs. $42-46)$, SD (72- 75 vs. $62-66), \mathrm{W}(73-75$ vs. $58-62)$, Ti III ( $89-97$ vs. $68-76)$ and palpal tibial accessory claw entire (vs. bifid in $H$. stanislavae), number of normal setae on Ti I (12 vs. 13), number of normal setae on TFe I ( 8 vs. 7 ), absence of microseta on Ti II (vs. present in H. stanislavae), fn Ta (24-21-18 vs. 23-19-19), from $H$. silesiacus by longer AM (33- 42 vs. 20 - 34), number of dorsal idiosomal setae (fD) (46 vs. 53), number of ventral idiosomal setae (fV) ( 39 vs. 57 ) and NDV ( 85 vs. 110), presence of Cp on Ta I and II (vs. absent in H. silesiacus), presence of microseta on Ge I and II (vs. absent in H. silesiacus), presence of microseta on Ti I and II (vs. absent in H. silesiacus), number of normal setae on Ge II and III (9 vs. 8), number of normal setae on Ti II (13 vs. 11); from $H$. viburnicola in the number of normal setae on Ta III (17 vs. 20$)$, longer W (73 - 75 vs. 54$)$, PW (64 - 66 vs. 51$)$, SB (17 - 19 vs. 12$)$, Ta I ( $62-66$ vs. 48$)$, shorter AL ( $26-30$ vs. 52$)$, AP (14 - 22 vs. 27), Ti I (64 - 70 vs. 90$)$, Ti II (64 - 67 vs. 80$)$ and Ge
I (62 - 67 vs. 80$)$; from $H$. yanlingica in the number of normal setae on Ti I (12 vs. 15), Ti III (13 vs. 12), fD (46 vs. 126$), \mathrm{fV}$ ( 45 vs. 158$)$, shorter SD (72 - 75 vs. 95$), \mathrm{W}(73-75$ vs. 122$)$, AW ( $46-52$ vs. 83$)$, PW (64 - 66 vs. 110$)$, AL ( $26-30$ vs. 73$)$, PL (42 47 vs. 117$), A M(33-42$ vs. 61$), 1 b$ (50 - 63 vs. 95$)$, $3 b$ ( $25-30$ vs. 55$)$, leg I ( $373-390$ vs. 606$)$, leg II (346 - 378 vs. 582$)$ and leg III ( $396-430$ vs. 679$)$; from $H$. sardiniensis by presence of Cp on Ta I and II (vs. absent in H. sardiniensis), presence of microseta on Ge I and II (vs. absent in H. sardiniensis), absence of microseta on Ti II (vs. present in H. sardiniensis), presence of eupathidium on Ta III (vs. absent in $H$. sardiniensis), presence of famulus on Ta II (vs. absent in $\mathrm{H}$. sardiniensis), presence of solenidion on Ge III (vs. absent in $H$. sardiniensis), palpal tibial accessory claw entire (vs. bifid in $H$. sardiniensis), number of normal setae on Ge I (11 vs. 8), TFe I (8 vs. 7), Ge II (9 vs. 8), Ti III (13 vs. 12), Ge III (9 vs. 8), number of eupathidium on Ta II (2 vs. 1), longer AW (4652 vs. 32$)$, PW ( $64-66$ vs. 42$)$, AL ( $26-30$ vs. 18$)$, PL ( $42-47$ vs. 30$), A M(33-42$ vs. 18$), S$ ( $50-63$ vs. 44), leg I ( 349 - 390 vs. 300$)$, leg II (346 - 378 vs. 280$)$, leg III (396 - 430 vs. 330) and IP (1107 - 1195 vs. 910) and from $H$. kotorensis by presence of $\mathrm{Cp}$ on Ta I and II (vs. absent in H. kotorensis), number of normal setae on BFe I-III (4 vs. 3), Ge II (9 vs. 10), Ge III (9 vs. 12), Ti II-III (13 vs. 12), presence of solenidion on Ge II (vs. absent in $H$. kotorensis), number of solenidion on Ti II (2 vs. 1), longer AW (46-52 vs. $36-38)$, PW (64 - 66 vs. $50-54), \mathrm{W}(73-75$ vs. $56-60)$, PL $(42-47$ vs. $32-34)$, AM ( $33-42$ vs. $24-26), 1 b$ (50 -63 vs. $36-40)$, Ti III $(89-97$ vs. $70-78)$, leg II $(346-378$ vs. $312-342)$, leg III $(396-430)$ vs. 360 - 380), IP (1107 - 1195 vs. 1026 - 1086) and shorter AP (14- 22 vs. $30-34)$ and from $H$. podorasensis by presence of $\mathrm{Cp}$ on Ta I and II (vs. absent in H. podorasensis), presence of famulus on Ta I (vs. absent in $H$. podorasensis), presence of microseta on Ge I and II (vs. absent in H. podorasensis), number of normal setae on Ti II and III (13 vs. 11), Ge II and III (9 vs. 8), BFe II \& III (4 vs. 3), Ta III (18 vs. 15), longer ISD (52- 62 vs. $32-46)$, SD (73- 75 vs. $44-56)$, W (7375 vs. $52-56)$, leg I ( $349-390$ vs. $260-274)$, leg II $(346-378$ vs. $242-264)$, leg III $(396-430$ vs. $268-$ $288)$ and IP (1107 - 1195 vs. $778-812)$. 


\section{ACKNOWLEDGEMENTS}

The authors are grateful to Dr. J. Makol for sending useful data on $H$. stanislavae and Dr. R. Haitlinger for sending useful data on $H$. silesiacus. This research was partly supported by a grant from the "Center of Excellence of Biological Control of Pests", Department of Plant Protection, College of Agriculture, University of Tehran, Karaj, Iran, which is greatly appreciated.

\section{REFERENCES}

Beron P. 1975 - Erythraeidae (Acariformes) larvaires de Bulgarie - Acta Zool. Bul., 1: 45-75.

Beron P. 2008 - Acarorum catalogus I, Acariformes: Calyptostomatoidea (Calyptostomatidae), Erythraeoidea (Smarididae, Erythraeidae) - Sofia. Pensoft and Natn. Mus. Nat. Hist., 272 pp.

Fain, A., Çobanoğlu, S. 1998 - Two new larval Erythraeidae (Acari) of the genus Hauptmannia Oudemans, 1910 from Turkey - Bul. Inst. Royal Sci. Nat. Belg., 68: 6369.

Gerson U., Smiley R.L., Ochoa R. 2003 - Mites (Acari) for pest control - Oxford, Blackwell Science, 539 pp. doi:10.1002/9780470750995

Greenslade, P.J.M., Southcott, R.V. 1980 - Parasitic mites on sminthurid Collembola in Australia - Entomol. Mon. Mag., 116: 85-88.

Haitlinger R. 1986 - The genus Hauptmannia Oudemans, 1910 (Acari, Prostigmata, Erythraeidae) in Poland Pol. Pismo Entomol., 56: 181-191.

Haitlinger R. 2007a - New species and records of mites (Acari, Prostigmata: Erythraeidae, Trombidiidae, Eu- trombidiidae) from the Balkan Peninsula - Biologia, 62: 67-77.

Haitlinger R., 2007b - New records of mites from Corsica and Sardinia, with descriptions of five new species (Acari: Prostigmata: Erythraeidae, Trombidiidae, Eutrombidiidae) - Genus, 18: 529-543.

Saboori A., Khaustov A., Hakimitabar M., Hajiqanbar H. 2009 - A new genus and species of larval Erythraeinae (Acari: Prostigmata: Erythraeidae) from Ukraine and the taxonomic state of Zhangiella Zootaxa, 2203: 22-30.

Saboori A., Pešić V., Hakimitabar M. 2008 — Some terrestrial mites (Acari: Prostigmata: Parasitengona) new to the fauna of Montenegro - In: Pešić V. (ed.) The book of abstracts and programme, III International Symposium of Ecologists of Montenegro, Herceg Novi, Montenegro, p. 89.

Southcott R.V. 1946 — Studies on Australian Erythraeidae (Acarina) - Proc. Linn. Soc. N. S. W., 71 (1-2): 6-48.

Walter D.E., Krantz G.W. 2009 - Collecting, rearing, and preparing specimens. In: Krantz G.W., Walter D.E. (Eds) A manual of Acarology, 3rd edition. Texas Tech University Press, pp. 83-96.

Zheng, B.-Y. 2002 - A new species of the genus Hauptmannia Oudemans, 1910 (Acari: Erythraeidae) from China - Acta Zootax. Sin., 27 (1): 89-91.

\section{COPYRIGHT}

(cc) EY-No-ND Saboori et al.. Acarologia is under free license. This open-access article is distributed under the terms of the Creative Commons-BY-NC-ND which permits unrestricted non-commercial use, distribution, and reproduction in any medium, provided the original author and source are credited. 